\title{
ANALISIS PENGARUH KEPEMILIKAN INSTITUSIONAL DAN KEPEMILIKAN MANAJERIAL TERHADAP KINERJA DAN NILAI PERUSAHAAN
}

\author{
Danies Rifky Akbar Darmawan Putra \\ Sekolah Bisnis dan Ekonomi, Universitas Prasetiya Mulya \\ Edu Town Kavling Edu I No. 1, Serpong, Jl. BSD Raya Utama, Pagedangan, \\ Tangerang, Banten 15339
}

\begin{abstract}
Conflict of interest between shareholder and management can trigger the increasing of cost production of the company and give an effect to the performance and value of the company. The purpose of this study is to examine the effect between ownership stuctures, the institutional and managerial ownership on the perfomance and value of companies. Based on the sample of 193 nonfinancial companies listed in Indonesia's Stocks Exchange for the period 2004 to 2015 by using purposive sampling method, institutional ownership gives positive effect on the perfomance and value of the companies, while managerial ownership gives negative effect on the perfomance as well as the value of the companies.
\end{abstract}

Keywords: Institutional Ownership, Managerial Ownership, Company Perfomance, Company Value

SARI PATI - Adanya konflik kepentingan antara pemegang saham dengan manajemen, dapat membuat perusahaan memiliki biaya keagenan dan memengaruhi kinerja serta nilai perusahan. Penelitian ini bertujuan untuk menjelaskan pengaruh hubungan dari struktur kepemilikan insitusional dan kepemilikan manajerial terhadap kinerja dan nilai perusahaan. Sampel penelitian menggunakan 193 perusahan nonkeuangan di Indonesia yang terdaftar di Bursa Efek Indonesia dari tahun 2004 - 2015 dengan metode purposive sampling. Hasil penelitian menunjukkan bahwa kepemilikan institusional berpengaruh positif terhadap kinerja dan nilai perusahaan, sedangkan kepemilikan manajerial berpengaruh negatif terhadap kinerja dan nilai perusahaan.

Kata Kunci: Kepemilikan Institusional, Kepemilikan Manajerial, Kinerja Perusahaan, Nilai Perusahaan.

\section{PENDAHULUAN}

Di era globalisasi, membeli saham yang diterbitkan oleh perusahaan merupakan salah satu pilihan untuk berinvestasi. Hal ini dilakukan oleh investor melalui penanaman modalnya di sebuah perusahaan untuk mendapatkan keuntungan. Faktanya, di dalam perusahaan terjadi konflik kepentingan antara pemegang saham dengan manajeman perusahaan. Menurut Jensen dan Meckling (1976) bahwa konflik keagenan antara pemegang saham dengan manajer perusahaan merupakan kecenderungan seorang manajer untuk mendapatkan keuntungannya. 
Salah satu solusi untuk mengatasi konflik keagenan antara pemegang saham dan manajemen perusahaan adalah meningkatkan pengendalian oleh pemegang saham melalui struktur kepemilikan.

Dua dimensi struktur kepemilikan menurut Mintzberg (1983) dalam Chaganti \& Damanpour 1991) adalah: pertama, 'Keterlibatan' dan 'ketidakterlibatan' yakni pemilik yang memengaruhi dan tidak memengaruhi keputusan. Kedua, 'Konsentrasi' dan 'tersebar' yakni perusahaan yang sahamnya dimiliki oleh pihak-pihak tertentu dan sahamnya dipegang oleh banyak pihak. Morck et al., (1988 dalam Heflin dan Shaw, 2000) membagi struktur kepemilikan menjadi dua yaitu kepemilikan terpusat atau blok dan kepemilikan tersebar. Kepemilikan terpusat atau blok adalah badan usaha yang memiliki minimal 5 persen saham perusahaan, misalnya: kepemilikan oleh institusi keuangan, perusahaan nonkeuangan, manajemen, keluarga, pemerintah, dan individual. Sedangkan, kepemilikan tersebar adalah pemegang saham di bawah 5 persen.

Penelitian ini menggunakan sampel dari kepemilikan terpusat yakni kepemilikan institusional dan kepemilikan manajerial. Kepemilikan institusional menurut Chaganti dan Damanpour (1991) adalah kepemilikan yang dimiliki oleh bank, dana pensiun, asosiasi tabungan dan pinjaman, perusahaan asuransi, dan lembaga pengelola reksadana. Sedangkan, kepemilikan manajerial yaitu kepemilikan saham yang dimiliki oleh anggota dewan direksi dan komisaris (de la Cruz et al., 2014). Menurut Joh (2003) bahwa kinerja perusahaan dapat diukur dengan profitabilitas akuntansi untuk mengevaluasi kinerja suatu perusahaan. Menurut Uno dan Kamiyama (2010) bahwa struktur kepemilikan dapat mempengaruhi nilai perusahaan yakni diukur dengan menggunakan Tobins ' $Q$ dan harga saham.

Penelitian ini merupakan analisis terhadap pengaruh kehadiran pemegang saham institusional dan kepemilikan manajerial terhadap kinerja dan nilai perusahaan dalam kurun waktu tahun 2004 - 2015. Penilaian kinerja perusahaan menggunakan profitabilitas akuntansi 
yakni variabel Return on Assets (ROA) dan Return on Equity (ROE), serta nilai perusahaan menggunakan Tobins ' $Q$ dan harga saham.

\section{LANDASAN TEORI DAN PENGEMBANGAN HIPOTESIS}

\section{Permasalahan Keagenan}

Fakta menunjukkan bahwa di dalam perusahaan terjadi konflik kepentingan antara pemegang saham dengan manajeman perusahaan. Prinsipal dalam permasalahan keagenan merupakan pemegang saham, dan agen adalah manajemen dari perusahaan tersebut. Hubungan keagenan menurut Jensen dan Meckling (1976) adalah kontrak antara prinsipal yang mempekerjakan orang lain (agen) untuk memberikan jasa atas kepentingan prinsipal yang melibatkan pendelegasian otoritas pembuat keputusan kepada agen. Menurut Ang et al. (2000) bahwa biaya keagenan muncul ketika kepentingan manajer (agen) tidak selaras dengan pemilik perusahaan (prinsipal). Biaya keagenan menurut Jensen dan Meckling (1976) adalah: pertama, biaya pengawasan dari prinsipal (the monitoring expenditures by the principal) yang meliputi : monitoring cost (biaya pengawasan), budget restriction (pembatasan anggaran), dan compensation policies (kebijakan kompensasi). Kedua, biaya pendekatan oleh agen (the bonding expenditures by the agent). Ketiga, kerugian residual (the residualloss).

Beberapa cara untuk mengurangi biaya keagenan menurut menurut Crutchley dan Hansen (1989) adalah: pertama, meningkatkan kepemilikan manajerial yakni menyamakan kepentingan manajer dengan pemegang saham. Kedua, membayar dividen lebih besar untuk menarik peluang modal dari luar sehingga meningkatkan pengawasan pada manajemen. Ketiga, menggunakan utang untuk mengurangi konflik antara manajer dengan pemegang saham. Pada umumnya, solusi yang digunakan untuk mengurangi biaya keagenan adalah meningkatkan kepemilikan manajerial karena tidak menambahkan biaya keagenan yang 
sudah ada.

\section{Struktur Kepemilikan Institusional dan Kepemilikan Manajerial}

Struktur kepemilikan menurut Mintzberg (1983, dalam Chaganti \& Damanpour, 1991) dibagi menjadi 2 dimensi, yaitu: pertama, keterlibatan' dan 'ketidakterlibatan' yakni keterlibatan dan ketidakterlibatan kepemilikan manajerial untuk memengaruhi secara langsung keputusan operasional perusahaan. Kedua, 'konsentrasi' dan 'tersebar' yakni kepemilikan blok saham oleh beberapa pihak yang mempunyai akses eksklusif untuk bertanggung jawab atas strategi operasi melalui pemantauan dan penelitian independen.

Kepemilikan institusional menurut Chaganti dan Damanpour (1991) adalah kepemilikan yang dimiliki oleh bank, dana pensiun, asosiasi tabungan dan pinjaman, perusahaan asuransi, dan lembaga pengelola reksadana. Menurut Bathala et al., (1994) kepemilikan institusional bertindak sebagai agen pengawasan yang efektif dan membantu mengurangi biaya agensi.

Kepemilikan manajerial menurut De La Cruz et al. (2014) adalah kepemilikan saham yang dimiliki oleh anggota dewan direksi dan komisaris. Jensen dan Meckling (1976) menyatakan bahwa jika perusahaan dikelola oleh pemilik saham, maka pemilik akan membuat keputusan operasional yang memaksimalkan utilitasnya. Menurut Berle dan Means (1932, dalam Demsetz \& Lehn 1985) serta Vo dan Nguyen (2014) bahwa kepemilikan manajerial dapat menimbulkan rasa memiliki terhadap perusahaan sehingga mengurangi konflik antara manajemen dan prinsipal.

\section{Kehadiran Kepemilikan Saham Institusional dan Saham Manajerial dengan Kinerja dan Nilai Perusahaan}

Hasil penelitian Morck et al., (1988), Rose (2005), Demsetz dan Villalonga (2001), dan Jusoh et al., (2014) menyatakan bahwa kehadiran pemegang saham institusional dan saham 
manajerial memiliki hasil negatif terhadap kinerja dan nilai perusahaan. Demikian sebaliknya, memiliki hubungan positif menurut penelitian Daraghma dan Alsinawi (2010), Demsetz dan Lehn (1985), serta Simoneti dan Gregoric (2004).

Faktor kepemilikan institusional dan manajerial yang mempengaruhi kinerja dan nilai perusahaan adalah return on asset (ROA), return on equality (ROE), Tobins ' $Q$, harga saham, ukuran perusahaan (size), pertumbuhan perusahaan (sales growth), leverage (debt to equity ratio), Firm Age, Current Ratio, Book Value Per Share, dan Earnings Per Share.

Hipotesis mengenai hubungan kepemilikan institusional dan manajerial terhadap kinerja dan nilai perusahaan adalah sebagai berikut:

\begin{tabular}{|l|l|}
\hline H1a & $\begin{array}{l}\text { Adanya pengaruh positif antara kehadiran pemegang saham } \\
\text { institusional terhadap Return on assets (ROA) perusahaan. }\end{array}$ \\
\hline H1b & $\begin{array}{l}\text { Adanya pengaruh positif antara kehadiran pemegang saham } \\
\text { institusional terhadap Return on equality (ROE) perusahaan. }\end{array}$ \\
\hline H1c & $\begin{array}{l}\text { Adanya pengaruh positif antara kehadiran pemegang saham } \\
\text { institusional terhadap Tobins ' } Q \text { perusahaan. }\end{array}$ \\
\hline H1d & $\begin{array}{l}\text { Adanya pengaruh positif antara kehadiran pemegang saham } \\
\text { institusional terhadap harga saham perusahaan. }\end{array}$ \\
\hline
\end{tabular}

Kerangka pemikiran antara struktur kepemilikan dengan kinerja dan nilai perusahaan dengan teori adalah sebagai berikut:

\begin{tabular}{|c|c|c|}
\hline $\begin{array}{l}\text { Variabel Independent } \\
\text { Struktur Kepemilikan: } \\
\text { 1. Kepemilikan saham } \\
\text { institusional. } \\
\text { 2. Kepemilikan saham } \\
\text { oleh manajemen } \\
\text { perusahaan }\end{array}$ & $\begin{array}{l}\text { Variabel Kontrol } \\
\text { 1. Size } \\
\text { - Accounting Profit } \\
\text { Rate (ROA dan } \\
\text { ROE) } \\
\text { 2. Nilai perusahaan } \\
\text { - Tobin' } Q \\
\text { - Harga saham }\end{array}$ & $\begin{array}{l}\text { Variabel Dependen } \\
\text { Kinerja perusahaan: } \\
\text { 1. Sales Growth } \\
\text { 2. Leverage (DER) } \\
\text { 3. Firm Age } \\
\text { 4. Current Ratio } \\
\text { 5. Book Value Per Share } \\
\text { 6. Earning Per Share }\end{array}$ \\
\hline
\end{tabular}

\section{METODE PENELITIAN}


Penelitian ini menggunakan teknik purposive sampling atas data kepemilikan dan data keuangan dari perusahaan yang terdaftar di Bursa Efek Indonesia (BEI) untuk periode 20042015 yang diakses dari situs Capital IQ. Kriteria sampel dan populasi adalah: (1) Perusahaan yang bergerak di seluruh sektor kecuali sektor keuangan terdaftar di BEI pada tahun 2015 . (2) Memiliki data kepemilikan institusional dan kepemilikan manajerial. (3) Memiliki data lengkap terkait variabel dependen dan variabel kontrol.

\section{Variabel Penelitian dan Definisi Operasional Variabel}

Varibel penelitian dan definisi operasional variable, meliputi: pertama, Variabel Kepemilikan Saham oleh Institutional (INS) yakni kepemilikan institusional yang dimiliki oleh bank, dana pensiun, asosiasi tabungan dan pinjaman, perusahaan asuransi, dan lembaga pengelola reksadana (Chaganti dan Damanpour,1991).

Kedua, Variabel Kepemilikan Saham oleh Manajemen Perusahaan (MAN) yakni kepemilikan manajerial terhadap saham perusahaan yang dimiliki oleh anggota dewan direksi dan komisaris de la Cruz et al., (2014).

Ketiga, Variabel Kinerja dan Nilai Perusahaan yakni variabel dependen yang digunakan untuk mengukur kinerja perusahaan dengan menggunakan rasio profitabilitas ROA (Return on Asset) yakni untuk mengukur efisiensi dari aset suatu perusahaan, dan ROE (Return on Equity) yakni untuk mengukur efisiensi dalam investasi oleh pemegang saham.

$$
\begin{aligned}
& \text { ROA }=\frac{\text { Pendapatan Bersih }}{\text { Total Aset }} \\
& \text { ROE }=\frac{\text { Pendapatan Bersih }}{\text { Total Ekuitas }}
\end{aligned}
$$

Nilai perusahaan diukur dengan menggunakan Tobins' $Q$ yakni mengukur kinerja dari segi pasar atau nilai pasar perusahaan. Nilai Q adalah rasio nilai pasar untuk biaya penggantian aset (Tobin dan Brainard, 1977). Davies et al., (2005) mengukur Q dengan menggunakan formula yaitu nilai pasar akhir tahun dari saham biasa, ditambah nilai buku 
akhir tahun saham preferen, ditambah nilai buku dari total utang, dibagi dengan total aset.

Tobin's $Q=($ Market Capitalization + Total Utang $)$ : total aset

Harga saham adalah indikator harga permintaan dari sekuritas di perdagangan bursa pada waktu tertentu (Musyoki, 2012).

Keempat, Variabel Kontrol menurut Adi (2013) adalah SIZE, SALESG, DER, AGE, CURAT, BVSHARE, dan EPS.

Tabel 1.1 Operasional Variabel

\begin{tabular}{|c|c|c|}
\hline Variabel & Simbol & Deskripsi Variabel \\
\hline $\begin{array}{l}\text { Variabel Independen } \\
\text { 1. Kepemilikan } \\
\text { Institusional } \\
\text { 2. Kepemilikan } \\
\text { Manajerial }\end{array}$ & $\begin{array}{l}\text { INS } \\
\text { MAN }\end{array}$ & $\begin{array}{l}\text { Persentase kepemilikan saham yang dimiliki oleh institusi } \\
\text { keuangan } \\
\text { Persentase kepemilikan saham yang dimiliki oleh dewan } \\
\text { direksi dan komisaris }\end{array}$ \\
\hline \multicolumn{3}{|l|}{ Variabel Dependen: } \\
\hline \multicolumn{3}{|l|}{ Kinerja Perusahaan } \\
\hline - Return on Asset & ROA & Rasio Pendapatan Bersih / Total Aset \\
\hline - Return on Equity & ROE & Rasio Pendapatan Bersih / Total Ekuitas \\
\hline \multicolumn{3}{|l|}{ Nilai Perusahaan } \\
\hline - Tobins'Q & $\mathrm{Q}$ & (Market Capitalization + Total Utang )/TotalAset \\
\hline - Harga Saham & SHAREP & Harga Saham 3 Bulan Setelah Akhir Periode \\
\hline \multicolumn{3}{|l|}{ Variabel Kontrol } \\
\hline Sales Growth Rate & SALESG & (Pendapatan 0-Pendapatan -1 )/Pendapatan -1 \\
\hline Firm Size & SIZE & Logaritma Natural dari Total Aset \\
\hline Leverage & DER & Total Utang / Total Ekuitas \\
\hline Firm Age & AGE (Years) & Umur Perusahaan \\
\hline Current Ratio & CURAT & Aset Lancar / Utang Lancar \\
\hline Book Value Per Share & BVSHARE & Nilai Buku Ekuitas / Jumlah Lembar Saham Beredar \\
\hline Earnings Per Share & EPS & $\begin{array}{l}\text { Pendapatan Bersih setelah Bunga dan Pajak/Jumlah Lembar } \\
\text { Saham Beredar }\end{array}$ \\
\hline
\end{tabular}

\section{Model Penelitian}

Model regresi berganda digunakan untuk menganalisis pengaruh antara kepemilikan saham insitusional dan kepemilikan manajerial terhadap kinerja dan nilai perusahaan melalui pembuktikan hipotesis model ROA, model ROE, Tobin' $Q$, dan harga saham.

(1) Formula Model ROA:

$$
\begin{aligned}
\text { ROAit }=\propto_{i t}+ & \beta_{1} \text { INS } i t+\beta_{2} \text { MANit }+\beta_{3} \text { SIZE } i t+\beta_{4} \text { SALESGit }+\beta_{5} \text { DERit }+\beta_{6} \text { AGE it } \\
& +\beta_{7} \text { CURAT it }+e_{i t}
\end{aligned}
$$

(2) Formula Model ROE:

$$
\begin{gathered}
\text { ROEit }=\propto_{i t}+\beta_{1} I N S i t+\beta_{2} \text { MANit }+\beta_{3} \text { SIZEit }+\beta_{4} \text { SALESGit }+\beta_{5} D E R i t+\beta_{6} \text { AGEit } \\
+\beta_{7} \text { CURAT } i t+e_{i t}
\end{gathered}
$$


(3) Tobins' $Q$ :

$$
\begin{aligned}
& Q_{i t}=\propto_{i t}+\beta_{1} I N S i t+\beta_{2} M A N i t+\beta_{3} S I Z E_{i t}+\beta_{4} S_{A L E S G i t}+\beta_{5} D E R i t+\beta_{6} A G E i t \\
& +\beta_{7} \text { CURAT } i t+e_{i t}
\end{aligned}
$$

(4) Harga Saham

$$
\begin{aligned}
\text { SHAREPit } & =\propto_{i t}+\beta_{1} \text { INSit }+\beta_{2} \text { MANit }+\beta_{3} \text { SIZEit }+\beta_{4} \text { SALESGit }+\beta_{5} \text { DERit } \\
& +\beta_{6} \text { AGEit }+\beta_{7} \text { CURATit }+\beta_{8} \text { BVSHAREit }+\beta_{9} \text { EPSit }+e_{i t}
\end{aligned}
$$

\section{Uji Asumsi Klasik}

Asumsi klasik Teori Ekonometrika menurut Gujarati (2003) dalam Model Gaussian, Model Standar, dan Classical Linear Regression Model (CLRM), yaitu: model regresi linear, nilai $\mathrm{X}$ selalu tetap atau nilai $\mathrm{X}$ yang independen terhadap faktor kesalahan, nilai rerata nol dari faktor gangguan $u$, homoskedastisitas atau keseragaman varians dari $u$, tidak adanya otokorelasi di antara gangguan, nol Kovarians antara $u i$ dan $x i$, jumlah observasi $n$ harus lebih besar daripada jumlah parameter yang akan diestimasi, kriteria dasar pada variabel X, model regresi ditentukan dengan benar, tidak ada multikolinearitas sempurna.

Uji asumsi klasik yang digunakan, yakni: pertama, Uji Normalitas mengasumsikan bahwa faktor gangguan $u i$ yang masuk dalam model regresi terdistribusi secara normal. Kedua, Uji Heteroskedastisitas adalah asumsi homoscedastisitas yaitu varians dari setiap gangguan jangka $u i$, tergantung pada nilai yang dipilih dari variabel penjelas memiliki beberapa nomor yang sama dengan $\sigma 2$. Jika asumsi ini tidak terpenuhi, maka terdapat heteroskedastisitas dimana tidak menghilangkan sifat ketidakbiasan dan konsistensi karakteristik dari estimator Ordinary Least Square (OLS). Jika estimator tersebut tidak memiliki varians minimum atau efisien, maka tidak bersifat estimator terbaik, linear, dan tidak bias (BLUE). Ketiga, Uji Otokorelasi adalah korelasi antara anggota serangkaian 
observasi dalam konteks regresi. Asumsi dari model regresi linear klasik adalah otokorelasi tidak ada dalam gangguan $u i$. “ Keempat, Uji Multikolinearitas adalah hubungan linear antara variabel-variabel penjelas dari model regresi yang "sempurna" dengan menggunakan dugaan informasi sebelumnya, mengombinasikan data cross-section dan time series, mengatasi variabel yang berkolinear, transformasi data, dan mencari data baru.

\section{Data Panel}

Data Panel menurut Gujarati (2003) adalah penelitian yang menggunakan gabungan data dari time series dan cross-section atau penelitian yang memiliki masing-masing objek dan jumlah tahun penelitian lebih dari satu. Metode yang dipakai dalam mengestimasi data panel menurut Park (2005), yaitu: pertama, Pooled Least Square adalah fungsi regresi yang mengelompokkan beberapa observasi dan mengolahnya secara bersamaan dengan asumsi komponen error dalam pengolahan ordinary least squares (OLS) dengan dua estimasi, serta menghilangkan kemungkinan terjadinya perbedaan di antara kedua sub periode waktu. Kedua, Fixed Effect Model yakni meneliti perbedaan antara intercept dengan asumsi slope yang sama dengan menggunakan Least Square Dummy Variable (LSDV) dan dalam metode estimasi efek. Ketiga, Random Effect Model yakni memperkirakan keragaman komponen untuk kelompok (atau waktu) dan error, dengan mengasumsikan intercept dan slope yang sama. Syarat nilai $\mu i$ tidak boleh berkorelasi dengan regressor karena bagian dari error dan diestimasikan dengan Generalized Least Squares (GLS) ketika matriks $\Omega$. Jika matriks $\Omega$ tidak diketahui, maka diestimasikan dengan metode Feasible Generalized Least Squares (FGLS).

\section{Pemilihan Model Data Panel}

Model yang digunakan untuk pengujian data panel menurut Park (2011), yakni: pertama, Uji Chow yakni pengujian untuk menentukan model persamaan antara Pooled Least 
Square (PLS) dengan Fixed Effect (FE). Syaratnya, nilai prob > F dibawah 0.05, maka model

FE adalah model yang cocok untuk regresi linear berganda. Kedua, Uji Lagrange multiplier (LM) yakni pengujian untuk menentukan model persamaan antara Pooled Least Square (PLS) dengan Random Effect (RE). Syaratnya, uji LM nilai prob > chi2 dibawah 0.05, maka model regresi yang digunakan adalah model RE. Ketiga, Uji Hausman yakni pengujian untuk menentukan persamaan antara Fixed Effect (FE) dengan Random Effect (RE). Syaratnya, prob > chi2 dibawah 0.05, maka model regresi yang digunakan adalah model FE.

\section{PEMBAHASAN}

Penelitian ini mengambil data dari Capital IQ dengan metode purpose sampling atas perusahaan nonkeuangan yang terdaftar di Bursa Efek Indonesia (BEI).

Tabel 1.2 Sampel Penelitian

\begin{tabular}{|l|c|c|}
\hline \multicolumn{1}{|c|}{ Keterangan } & Jumlah Perusahaan & Total Observasi \\
\hline Jumlah observasi perusahaan nonkeuangan periode 2004-2015 & 399 & 4788 \\
\hline $\begin{array}{l}\text { Observasi yang tidak memiliki kepemilikan institusional dan/ } \\
\text { atau manajerial }\end{array}$ & $(184)$ & $(3780)$ \\
\hline Observasi dengan data tidak lengkap dan data outliers & $(22)$ & $(135)$ \\
\hline Jumlah observasi yang digunakan sebagai sampel & $\mathbf{1 9 3}$ & $\mathbf{8 7 3}$ \\
\hline
\end{tabular}

\section{Analisis Data}

Analisis data yang digunakan untuk mengolah data kepemilikan dan keuangan, yaitu: Statistik Deskriptif, Analisis Korelasi, dan Uji Asumsi Klasik.

\section{(1) Statistik Deskriptif}

Tabel 1.3 Statistik Deskriptif

\begin{tabular}{|l|c|l|l|l|l|}
\hline \multicolumn{1}{|c|}{ Variabel } & Observasi & \multicolumn{1}{c|}{ Mean } & Std. Deviasi & \multicolumn{1}{c|}{ Min } & \multicolumn{1}{c|}{ Max } \\
\hline INS & 873 & 0.1317899 & 0.1404378 & 0.00011 & 0.7826 \\
\hline MAN & 873 & 0.0577 & 0.1189305 & 0.00001 & 0.81 \\
\hline ROA & 873 & 0.0607023 & 0.0760779 & -0.258127 & 0.360478 \\
\hline ROE & 873 & 0.1049782 & 0.1431647 & -0.483485 & 0.67307 \\
\hline Q & 873 & 2.199139 & 1.35607 & 0.228 & 6.93115 \\
\hline SHAREP & 873 & 2287.728 & 4144.791 & 29.04 & 20378.8 \\
\hline Total Aset (miliar rupiah) & 873 & 10,400 & 21,700 & 45 & 250,000 \\
\hline SIZE (ln Total Aset) & 873 & 15.06517 & 1.516041 & 10.707 & 19.319 \\
\hline SALESG & 873 & 0.1540038 & 0.2786668 & -0.83871 & 1.16877 \\
\hline DER & 873 & 0.652057 & 0.7016102 & 0 & 3.67448 \\
\hline YEARS & 873 & 35.75601 & 22.86932 & 4 & 198 \\
\hline
\end{tabular}




\begin{tabular}{|l|l|l|l|l|l|}
\hline AGE $(\ln$ YEARS) & 873 & 3.423585 & 0.567152 & 1.386 & 5.288 \\
\hline CURAT & 873 & 2.080724 & 1.571046 & 0.08 & 7.90054 \\
\hline BVSHARE & 873 & 1088.586 & 1685.27 & 37.6281 & 7819.48 \\
\hline EPS & 873 & 155.1729 & 308.8149 & -514.126 & 1442.94 \\
\hline
\end{tabular}

Hasil penjabaran teknik winsorizing menjadi mean(-3) dan (+3), dan standar deviasi untuk variabel ROA, ROE, Q, SHAREP, SALESG, DER, CURAT, BVSHARE, dan EPS menghasilkan: (1) Return on Assets (ROA) memiliki rata-rata sebesar 6.07 persen berarti perusahan mendapatkan 6.07 persen pendapatan bersih dari total asetnya. (2) Return on Equity (ROE) memiliki rata-rata sebesar 10.50 persen berarti perusahaan mendapatkan 10.50 pendapatan bersih dari ekuitasnya. (3) Tobins' $Q$ memiliki rata- rata sebesar 2.199139 lebih dari 1 yang menunjukkan nilai perusahaan baik. (4) Harga Saham (SHAREP) memiliki ratarata sebesar 2,287.728.

\section{(2) Analisis Korelasi}

Tabel 1.4 Analisis Korelasi Pairwise

\begin{tabular}{|c|c|c|c|c|c|c|}
\hline & INS & MAN & ROA & ROE & $\mathrm{Q}$ & SHAREP \\
\hline INS & 1.0000 & & & & & \\
\hline \multirow[t]{2}{*}{ MAN } & 0.0086 & 1.0000 & & & & \\
\hline & 0.8004 & & & & & \\
\hline \multirow[t]{2}{*}{ ROA } & 0.0082 & $-0.1278 * * *$ & 1.0000 & & & \\
\hline & 0.8090 & 0.0002 & & & & \\
\hline \multirow[t]{2}{*}{ ROE } & 0.0195 & $-0.1456^{* * *}$ & $0.8936^{* * * *}$ & 1.0000 & & \\
\hline & 0.5647 & 0.0000 & 0.0000 & & & \\
\hline \multirow[t]{2}{*}{$\mathrm{Q}$} & $0.0634^{*}$ & -0.0116 & $0.4434 * * *$ & $0.4404 * * *$ & 1.0000 & \\
\hline & 0.0613 & 0.7322 & 0.0000 & 0.0000 & & \\
\hline \multirow[t]{2}{*}{ SHAREP } & $-0.0628 *$ & -0.0501 & $0.3910^{* * *}$ & $0.2966^{* * *} *$ & $0.3195 * * *$ & 1.0000 \\
\hline & 0.0635 & 0.1390 & 0.0000 & 0.0000 & 0.0000 & \\
\hline \multirow[t]{2}{*}{ SIZE } & $-0.0588^{*}$ & $-0.1555^{* * *}$ & $0.0930 * * *$ & $0.1108 * * *$ & $0.1407 * * *$ & $0.4088^{* * * *}$ \\
\hline & 0.0825 & 0.0000 & 0.0060 & 0.0010 & 0.0000 & 0.0000 \\
\hline \multirow[t]{2}{*}{ SALESG } & 0.0148 & -0.0188 & $0.2021 * * *$ & $0.2612 * * *$ & $0.1275 * * *$ & -0.0091 \\
\hline & 0.6625 & 0.5784 & 0.0000 & 0.0000 & 0.0002 & 0.7876 \\
\hline \multirow[t]{2}{*}{ DER } & 0.0088 & -0.0423 & $-0.4611 * * *$ & $-0.3323^{* * *}$ & -0.0397 & $-0.1556^{* * *}$ \\
\hline & 0.7959 & 0.2113 & 0.0000 & 0.0000 & 0.2412 & 0.0000 \\
\hline \multirow[t]{2}{*}{ AGE } & $-0.0864 * *$ & -0.0456 & $0.1233^{* * *}$ & $0.1106 * * *$ & $0.0810 * *$ & $0.1140 * * *$ \\
\hline & 0.0106 & 0.1785 & 0.0003 & 0.0011 & 0.0166 & 0.0007 \\
\hline \multirow[t]{2}{*}{ CURAT } & $-0.0776^{* *}$ & 0.0482 & $0.3699 * * *$ & $0.2087 * * *$ & -0.0126 & 0.0515 \\
\hline & 0.0219 & 0.1551 & 0.0000 & 0.0000 & 0.7100 & 0.1286 \\
\hline \multirow[t]{2}{*}{ BVSHARE } & $-0.1296 * * *$ & $-0.1118 * * *$ & $0.2519 * * *$ & $0.1688 * * *$ & 0.0441 & $0.8039 * * *$ \\
\hline & 0.0001 & 0.0009 & 0.0000 & 0.0000 & 0.1933 & 0.0000 \\
\hline \multirow[t]{2}{*}{ EPS } & $-0.0568^{*}$ & -0.1549 *** & 0.5637 *** & $0.4797 * * *$ & 0.2777 *** & 0.8752 *** \\
\hline & 0.0937 & 0.0000 & 0.0000 & 0.0000 & 0.0000 & 0.0000 \\
\hline
\end{tabular}

Lanjutan dari Tabel 1.4. Analisis Korelasi Pairwise

\begin{tabular}{|l|l|l|l|l|l|l|l|}
\hline & SIZE & SALESG & DER & AGE & CURAT & BVSHARE & EPS \\
\hline INS & & & & & & & \\
\hline & & & & & & & \\
\hline MAN & & & & & & & \\
\hline
\end{tabular}




\section{saki}

Studi Akuntansi \& Keuangan Indonesia

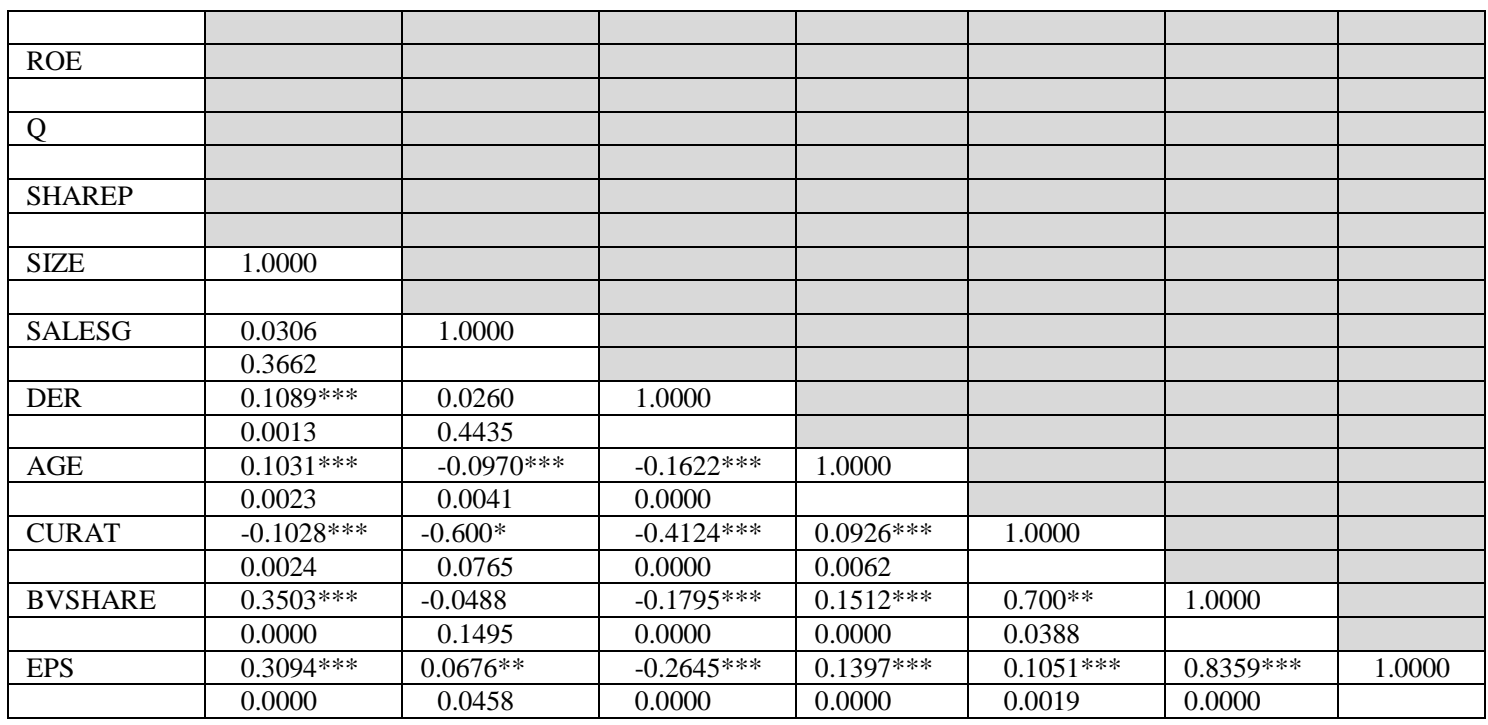

Berdasarkan tabel 1.4, terdapat beberapa korelasi antar variabel, yaitu: (1) Variabel INS adanya hubungan signifikan pada level 1 persen dengan BVSHARE, level 5 persen dengan AGE, CURAT, dan level 10 persen dengan Q, SHAREP, SIZE, EPS. (2) Variabel MAN adanya hubungan signifikan pada level 1 persen dengan ROA, ROE, SIZE, BVSHARE, EPS. (3) Variabel ROA adanya hubungan signifikan pada level 1 persen dengan ROE, Q, SHAREP, SIZE, SALESG, DER, AGE, CURAT, BVSHARE, EPS. (4) Variabel ROE adanya hubungan signifikan pada level 1 persen dengan Q, SHAREP, SIZE, SALESG, DER, AGE, CURAT, BVSHARE, EPS. (5) Variabel Q adanya hubungan signifikan pada level 1 persen dengan SHAREP, SIZE, SALESG, dan EPS, level 5 persen dengan AGE. (6) Variabel SHAREP adanya hubungan signifikan pada level 1 persen dengan SIZE, DER, AGE, BVSHARE, dan EPS.

(3) Uji Asumsi Klasik, meliputi: Uji Normalitas, Uji Heteroskedastisitas, Uji Otokorelasi, dan Uji Multikolineritas.

(3.1) Uji Normalitas

Tabel 1.5 Uji Normalitas

\begin{tabular}{|l|l|l|}
\hline \multicolumn{1}{|c|}{ Variabel } & Skewness & Kurtosis \\
\hline INS & 1.970592 & 7.768768 \\
\hline MAN & 3.562177 & 17.47939 \\
\hline ROA & 0.0057878 & 0.6624958 \\
\hline
\end{tabular}




\begin{tabular}{|l|l|l|}
\hline ROE & -0.6565065 & 7.72905 \\
\hline Q & 1.46714 & 5.073819 \\
\hline SHAREP & 3.080623 & 12.57978 \\
\hline SIZE & 0.0247347 & 2.662085 \\
\hline SALESG & 0.8992255 & 5.794612 \\
\hline DER & 1.93577 & 7.525129 \\
\hline AGE & -0.5236488 & 4.87463 \\
\hline CURAT & 2.006808 & 7.140651 \\
\hline BVSHARE & 2.841514 & 10.69846 \\
\hline EPS & 2.733398 & 10.63994 \\
\hline
\end{tabular}

Berdasarkan tabel 1.5, nilai skewness di antara (-3) hingga (3) dan kurtosis di bawah 10, maka semua variabel merupakan data normal, kecuali MAN dan SHAREP.

(3.2) Uji Heteroskedastisitas

Tabel 1.6 Uji Modified Wald Model 1

\begin{tabular}{|r|c|c|}
\hline $\begin{array}{r}\text { Wald test for groupwise heteroskedasticity in } \\
\text { fixed effect model regression model }\end{array}$ & $:$ & H0: $\operatorname{sigma}(\mathrm{i})^{\wedge} 2=\operatorname{sigma}^{\wedge} 2$ for alli \\
\hline chi2 $(192)$ & $=$ & $1.1 \mathrm{e}+36$ \\
\hline Prob $>$ chi2 & $=$ & 0.0000 \\
\hline
\end{tabular}

Tabel 1.7 Uji Modified Wald Model 2

\begin{tabular}{|r|c|c|}
\hline $\begin{array}{r}\text { Wald test for groupwise heteroskedasticity in } \\
\text { fixed effect model regression model }\end{array}$ & $:$ & H0: $\operatorname{sigma}(\mathrm{i}) \wedge 2=\operatorname{sigma}^{\wedge} 2$ for alli \\
\hline chi2 $(192)$ & $=$ & $4.9 \mathrm{e}+34$ \\
\hline Prob $>$ chi2 & $=$ & 0.0000 \\
\hline
\end{tabular}

Tabel 1.8 Uji Modified Wald Model 3

\begin{tabular}{|r|c|c|}
\hline $\begin{array}{r}\text { Wald test for groupwise heteroskedasticity in } \\
\text { fixed effect model regression model }\end{array}$ & $:$ & H0: $\operatorname{sigma}(\mathrm{i})^{\wedge} 2=\operatorname{sigma}^{\wedge} 2$ for alli \\
\hline chi2 $(192)$ & $=$ & $1.0 \mathrm{e}+34$ \\
\hline Prob $>$ chi2 & $=$ & 0.0000 \\
\hline
\end{tabular}

Tabel 1.9 Uji Modified Wald Model 4

\begin{tabular}{|r|c|c|}
\hline $\begin{array}{r}\text { Wald test for groupwise heteroskedasticity in } \\
\text { fixed effect model regression model }\end{array}$ & $:$ & H0: $\operatorname{sigma}(\mathrm{i})^{\wedge} 2=\operatorname{sigma}^{\wedge} 2$ for alli \\
\hline chi2 $(192)$ & $=$ & $2.4 \mathrm{e}+07$ \\
\hline Prob $>$ chi2 & $=$ & 0.0000 \\
\hline
\end{tabular}

Berdasarkan table 1.6-1.9, nilai prob > chi2 0.0000, maka ketiga model penelitian memiliki masalah heteroskedastisitas sehingga perlu diestimasikan menggunakan xtreg robust di input Stata.

(3.3) Uji Otokorelasi

Tabel 1.10 Uji Woolridge Model 1

\begin{tabular}{l|l|l} 
Wooldridge Test for H0 & $:$ & no first order autocorrelation
\end{tabular} 


\begin{tabular}{|r|r|r|}
\hline $\mathrm{F}(1,111)$ & $=$ & 2.702 \\
\hline Prob $>\mathrm{f}$ & $=$ & 0.1031 \\
\hline
\end{tabular}

Tabel 1.11 Uji Woolridge Model 2

\begin{tabular}{|r|c|c|}
\hline Wooldridge Test for H0 & $:$ & no first order autocorrelation \\
\hline $\mathrm{F}(1,111)$ & $=$ & 2.475 \\
\hline Prob $>\mathrm{f}$ & $=$ & 0.1185 \\
\hline
\end{tabular}

Tabel 1.12 Uji Woolridge Model 3

\begin{tabular}{|r|c|c|}
\hline Wooldridge Test for H0 & $:$ & no first order autocorrelation \\
\hline $\mathrm{F}(1,111)$ & $=$ & 23.332 \\
\hline Prob $>\mathrm{f}$ & $=$ & 0.0000 \\
\hline
\end{tabular}

Tabel 1.13 Uji Woolridge Model 4

\begin{tabular}{|r|c|c|}
\hline Wooldridge Test for $\mathrm{H} 0$ & $:$ & no first order autocorrelation \\
\hline $\mathrm{F}(1,111)$ & $=$ & 19.125 \\
\hline Prob $>\mathrm{f}$ & $=$ & 0.0000 \\
\hline
\end{tabular}

Berdaskan tabel 1.10-1.13, (1) Nilai nilai prob > f dibawah 0.05, maka model 3 dan model 4 memiliki masalah otokorelasi sehingga perlu diestimasikan menggunakan perintah $x t s c c$ di Stata. (2) Nilai prob > f di atas 0.05, maka model 1 dan model 2 tidak memiliki masalah otokorelasi.

(3.4) Uji Multikolineritas

Tabel 1.14 Uji Multikolinearitas

\begin{tabular}{|l|c|c|c|c|}
\hline \multicolumn{2}{|c|}{ Model 1,2, dan 3 } & \multicolumn{2}{c|}{ Model 4 } \\
\hline Variabel & VIF & 1/VIF & VIF & 1/VIF \\
\hline SIZE & 1.06 & 0.944283 & 1.22 & 0.821940 \\
\hline AGE & 1.06 & 0.940601 & 1.07 & 0.936055 \\
\hline SALESG & 1.01 & 0.986229 & 1.06 & 0.942692 \\
\hline CURAT & 1.22 & 0.817407 & 1.22 & 0.816823 \\
\hline DER & 1.24 & 0.805354 & 1.35 & 0.741094 \\
\hline INS & 1.02 & 0.983198 & 1.04 & 0.962329 \\
\hline MAN & 1.03 & 0.973074 & 1.05 & 0.954290 \\
\hline BVSHARE & - & - & 3.67 & 0.272786 \\
\hline EPS & - & - & 3.74 & 0.267696 \\
\hline MEAN VIF & \multicolumn{2}{|c|}{$\mathbf{1 . 0 9}$} & \multicolumn{1}{|c}{} \\
\hline
\end{tabular}

Berdasarkan tabel 1.14, nilai VIF dari setiap variable lebih kecil dari 10 untuk model 1,2,3, dan 4, maka antar variabel independen tidak memiliki masalah multikolinearitas.

\section{Uji Pemilihan Model}

Pendekatan yang digunakan untuk menentukan model regresi data panel, yakni: 
Pooled Least Squares (PLS), atau Fixed Effect (FE), dan Random Effect (RE). Sedangkan, pengujian penelitian untuk menentukan model regresi linear berganda menggunakan Uji Hausman, Uji LM, dan Uji Chow.

(1) Uji Chow.

Tabel 1.15 Uji Chow Model 1

\begin{tabular}{|r|c|c|}
\hline \multirow{2}{*}{ Chow Test for H0 against Ha } & $:$ & Pooled Least Squares \\
\cline { 2 - 4 } & $:$ & Fixed Effect \\
\hline $\mathrm{F}(7,673)$ & $=$ & 29.15 \\
\hline Prob $>\mathrm{F}$ & $=$ & 0.0000 \\
\hline
\end{tabular}

Tabel 1.16 Uji Chow Model 2

\begin{tabular}{|r|c|c|}
\hline \multirow{2}{*}{ Chow Test for H0 against Ha } & $:$ & Pooled Least Squares \\
\cline { 2 - 4 } & $:$ & Fixed Effect \\
\hline $\mathrm{F}(7,673)$ & $=$ & 24.85 \\
\hline Prob $>\mathrm{F}$ & $=$ & 0.0000 \\
\hline
\end{tabular}

Tabel 1.17 Uji Chow Model 3

\begin{tabular}{|r|c|c|}
\hline \multirow{2}{*}{ Chow Test for H0 against Ha } & $:$ & Pooled Least Squares \\
\cline { 2 - 4 } & $:$ & Fixed Effect \\
\hline $\mathrm{F}(7,673)$ & $=$ & 10.56 \\
\hline Prob $>\mathrm{F}$ & $=$ & 0.0000 \\
\hline
\end{tabular}

Tabel 1.18 Uji Chow Model 4

\begin{tabular}{|r|c|c|}
\hline \multirow{2}{*}{ Chow Test for H0 against Ha } & $:$ & Pooled Least Squares \\
\cline { 2 - 4 } & $:$ & Fixed Effect \\
\hline $\mathrm{F}(9,671)$ & $=$ & 105.95 \\
\hline Prob $>\mathrm{F}$ & $=$ & 0.0000 \\
\hline
\end{tabular}

Berdasarkan tabel 1.15-1.18, nilai prob > F dibawah 0.05, maka memiliki persamaan Fixed Effect (FE).

(2) Uji LM

Tabel 1.19 Uji LM Model 1

\begin{tabular}{|r|c|c|}
\hline \multirow{2}{*}{ LM Test for H0 against Ha } & $:$ & Pooled Least Squares \\
\cline { 2 - 3 } & $:$ & Random Effect \\
\hline chi2 $(01)$ & $=$ & 460.65 \\
\hline Prob > chi2 & $=$ & 0.0000 \\
\hline
\end{tabular}

Tabel 1.20 Uji LM Model 2

\begin{tabular}{|r|c|c|}
\hline \multirow{2}{*}{ LM Test for H0 against Ha } & $:$ & Pooled Least Squares \\
\cline { 2 - 4 } & $:$ & Random Effect \\
\hline chi2 $(01)$ & $=$ & 229.28 \\
\hline Prob $>$ chi2 & $=$ & 0.0000 \\
\hline
\end{tabular}

Tabel 1.21 Uji LM Model 3

\begin{tabular}{|r|c|c|}
\hline \multirow{2}{*}{ LM Test for H0 against Ha } & $:$ & Pooled Least Squares \\
\cline { 2 - 4 } & $:$ & Random Effect \\
\hline chi2 $(01)$ & $=$ & 881.97 \\
\hline
\end{tabular}




\begin{tabular}{|r|r|r|}
\hline Prob $>$ chi2 & $=$ & 0.0000 \\
\hline
\end{tabular}

Tabel 1.22 Uji LM Model 4

\begin{tabular}{|r|c|c|}
\hline \multirow{2}{*}{ LM Test for H0 against Ha } & $:$ & Pooled Least Squares \\
\cline { 2 - 4 } & $:$ & Random Effect \\
\hline chi2 $(01)$ & $=$ & 146.25 \\
\hline Prob $>$ chi2 & $=$ & 0.0000 \\
\hline
\end{tabular}

Berdasarkan tabel 1.19-1.22, nilai prob > chi2 dibawah 0.05, maka memiliki model Random Effect (RE).

(3) Uji Hausman

Tabel 1.23 Uji Hausman Model 1

\begin{tabular}{|r|c|c|}
\hline \multirow{2}{*}{ Hausman Test for H0 against Ha } & $:$ & Random Effect \\
\cline { 2 - 4 } & $:$ & Fixed Effect \\
\hline chi2 (7) & $=$ & 16.03 \\
\hline Prob > chi2 & $=$ & 0.0248 \\
\hline
\end{tabular}

Tabel 1.24 Uji Hausman Model 2

\begin{tabular}{|r|c|c|}
\hline Hausman Test for H0 against Ha & $:$ & Random Effect \\
\cline { 2 - 4 } & $:$ & Fixed Effect \\
\hline chi2 (7) & $=$ & 12.93 \\
\hline Prob $>$ chi2 & $=$ & 0.0737 \\
\hline
\end{tabular}

Tabel 1.25 Uji Hausman Model 3

\begin{tabular}{|r|c|c|}
\hline Hausman Test for H0 against $\mathrm{Ha}$ & $:$ & Random Effect \\
\hline & $:$ & Fixed Effect \\
\hline chi2 (7) & $=$ & 22.77 \\
\hline Prob $>$ chi2 & $=$ & 0.0019 \\
\hline
\end{tabular}

Tabel 1.26 Uji Hausman Model 4

\begin{tabular}{|r|c|c|}
\hline Hausman Test for H0 against Ha & $:$ & Random Effect \\
\hline & $:$ & Fixed Effect \\
\hline chi2 (8) & $=$ & 67.06 \\
\hline Prob > chi2 & $=$ & 0.0000 \\
\hline
\end{tabular}

Berdasarkan tabel 1.23-1.26, (1) nilai prob > chi2 dibawah 0.05, maka model 1, 3 dan 4 memiliki model Fixed Effect (FE). (2) Nilai prob > chi2 di atas 0.05, maka model 2 memiliki model Random Effect (RE).

Kesimpulan hasil Uji Hausman, Uji LM, dan Uji Chow adalah: (1) Persamaan model 1, 3, dan 4 memiliki model regresi Fixed Effect (FE). (2) Persamaan model 2 memiliki model regresi Random Effect $(\mathrm{FE})$. 


\section{saki}

Studi Akuntansi \& Keuangan Indonesia

\section{Uji Hipotesis}

Uji hipotesis regresi linear bertujuan untuk membuktikan hipotesis yang ditulis sebelumnya, yakni: (1) Hipotesis 1 menguji persamaan model 1,3,4 dengan model Fixed Effect (FE). (2) Hipotesis 1 menguji persamaan model 2 dengan model Random Effect (RE).

Tabel 1.27 Hasil Uji Hipotesis Model 1

\begin{tabular}{|c|c|c|c|c|c|}
\hline \multicolumn{2}{|c|}{$\begin{array}{r}\text { Number of Obs. } \\
\text { Number of Groups } \\
\text { Prob > F } \\
\text { Within R-Squared }\end{array}$} & \multicolumn{4}{|l|}{$\begin{array}{l}873 \\
193 \\
0.0000 \\
0.2326\end{array}$} \\
\hline ROA & Coef. & Std. Error & $\mathrm{t}$ & $\mathrm{P}>|\mathrm{t}|$ & $\mathrm{P}>|\mathrm{t}| / 2$ \\
\hline INS & 0.0618939 & 0.040331 & 1.53 & 0.127 & $0.0635^{*}$ \\
\hline MAN & -0.0857692 & 0.111784 & -0.77 & 0.444 & 0.222 \\
\hline SIZE & -0.0132892 & 0.0105875 & 1.26 & 0.211 & 0.1055 \\
\hline SALESG & 0.0593867 & 0.01132 & 5.25 & 0.000 & $0.000 * * *$ \\
\hline DER & -0.0409069 & 0.007001 & -5.84 & 0.000 & $0.000 * * *$ \\
\hline AGE & -0.0638146 & 0.0465464 & -1.37 & 0.172 & $0.086^{*}$ \\
\hline CURAT & 0.0065299 & 0.0029668 & 2.20 & 0.029 & $0.015 * *$ \\
\hline Constants & 0.0797069 & 0.089083 & 0.89 & 0.372 & 0.186 \\
\hline
\end{tabular}

Tabel 1.28 Hasil Uji Hipotesis Model 2

\begin{tabular}{|c|c|c|c|c|c|}
\hline \multicolumn{2}{|c|}{$\begin{array}{r}\text { Number of Obs. } \\
\text { Number of Groups } \\
\text { Prob }>\mathrm{F} \\
\text { within R-Squared }\end{array}$} & $\begin{array}{l}873 \\
193 \\
0.0000 \\
0.1943\end{array}$ & & & \\
\hline ROE & Coef. & Std. Error & $\mathrm{Z}$ & $\overline{\mathrm{P}>|\mathrm{z}|}$ & $\mathrm{P}>\mid \mathrm{t} / / 2$ \\
\hline INS & 0.0473431 & 0.0463152 & 1.02 & 0.307 & 0.154 \\
\hline MAN & -0.1033305 & 0.0447909 & -2.31 & 0.021 & $0.011 * * *$ \\
\hline SIZE & 0.0081482 & 0.004506 & 1.81 & 0.071 & $0.036 * *$ \\
\hline SALESG & 0.1378435 & 0.0242811 & 5.68 & 0.000 & $0.000 * * *$ \\
\hline DER & -0.0633574 & 0.0167122 & -3.79 & 0.000 & $0.000 * * *$ \\
\hline AGE & 0.0085864 & 0.0136256 & 0.63 & 0.529 & 0.265 \\
\hline CURAT & 0.0095782 & 0.0034129 & 2.81 & 0.005 & $0.003^{* * *}$ \\
\hline Constants & -0.0530078 & 0.076528 & -0.69 & 0.489 & 0.245 \\
\hline
\end{tabular}

Tabel 1.29 Hasil Uji Hipotesis Model 3

\begin{tabular}{|c|c|c|c|c|c|}
\hline \multicolumn{2}{|c|}{$\begin{array}{r}\text { Number of Obs. } \\
\text { Number of Groups } \\
\text { Prob > F } \\
\text { within R-Squared }\end{array}$} & $\begin{array}{l}873 \\
193 \\
0.0000 \\
0.0989\end{array}$ & & & \\
\hline Q & Coef. & Std. Error & $\mathrm{T}$ & $P>|t|$ & $\mathrm{P}>\mid \mathrm{t} / / 2$ \\
\hline INS & 3.240858 & 0.3122664 & 10.38 & 0.000 & $0.000 * * *$ \\
\hline MAN & -1.286853 & 1.183163 & -1.09 & 0.278 & 0.139 \\
\hline SIZE & 0.2479038 & 0.1876326 & 1.32 & 0.188 & $0.094^{*}$ \\
\hline SALESG & 0.4763885 & 0.2167036 & 2.20 & 0.029 & $0.015 * *$ \\
\hline DER & 0.0948809 & 0.0417281 & 2.27 & 0.024 & $0.012 * * *$ \\
\hline AGE & -1.102952 & 0.2626339 & -4.20 & 0.000 & $0.000 * * *$ \\
\hline CURAT & -0.0601325 & 0.0285684 & -2.10 & 0.037 & $0.019 * *$ \\
\hline Constants & 1.877498 & 2.417883 & 0.78 & 0.438 & 0.219 \\
\hline
\end{tabular}

Tabel 1.30 Hasil Uji Hipotesis Model 4 


\begin{tabular}{|c|c|c|c|c|c|}
\hline \multicolumn{2}{|c|}{$\begin{array}{r}\text { Number of Groups } \\
\text { Prob > F } \\
\text { within R-Squared }\end{array}$} & $\begin{array}{l}193 \\
0.0000 \\
0.5870\end{array}$ & & & \\
\hline SHAREP & Coef. & Std. Error & $\mathrm{t}$ & $P>|t|$ & $\mathrm{P}>|\mathrm{t}| / 2$ \\
\hline INS & 348.0086 & 553.0272 & 0.63 & 0.530 & 0.265 \\
\hline MAN & -4047.063 & 990.8403 & -4.08 & 0.000 & $0.000^{* * *}$ \\
\hline SIZE & 912.0405 & 286.9236 & 3.39 & 0.001 & $0.001 * * *$ \\
\hline SALESG & -327.7391 & 200.6358 & -1.63 & 0.104 & $0.052 * *$ \\
\hline DER & 264.6189 & 82.80825 & 3.20 & 0.002 & $0.001 * * *$ \\
\hline $\mathrm{AGE}$ & -1710.85 & 319.3447 & -5.36 & 0.000 & $0.000 * * *$ \\
\hline CURAT & 2.130287 & 51.24362 & 0.04 & 0.967 & 0.484 \\
\hline BVSHARE & 1.349462 & 0.2550169 & 5.29 & 0.000 & $0.000 * * *$ \\
\hline EPS & 5.96611 & 1.00774 & 5.92 & 0.000 & $0.000^{* * *}$ \\
\hline Constants & -8832.638 & 3424.328 & -2.58 & 0.011 & $0.006^{* * *}$ \\
\hline
\end{tabular}

Keterangan: $* * *)$ : signifikansi level 1 persen; **): signifikansi level 5 persen; *): signifikansi level 10 persen

\section{Pengaruh Kepemilikan Institusional dan Kepemilikan Manajerial Terhadap Kinerja dan Nilai Perusahaan}

Pengaruh kepemilikan institusional dan kepemilikan manajerial terhadap kinerja dan nilai perusahaan dapat disimpulkan dari hasil uji regresi terhadap suatu hipotesis, yaitu:

\section{(1.1) Hipotesis I:}

Adanya pengaruh positif antara kehadiran pemegang saham institusional terhadap kinerja dan nilai perusahaan.

\section{(1.2) Hasil Uji Regresi:}

1. Nilai signifikansi level 10 persen (ROA) menunjukkan hubungan positif yang signifikan antara kepemilikan saham institusional dengan kinerja perusahaan.

2. Adanya hubungan negatif (ROE) antara kepemilikan saham institusional dengan kinerja perusahaan.

3. Nilai Q pada signifikansi level 1 persen menunjukkan hubungan positif yang signifikan antara kepemilikan saham institusional dengan nilai perusahaan.

4. Tidak ada hubungan signifikan antara kepemilikan saham institusional dengan harga saham. 
Kesimpulan :

Terbukti karena semakin besar kepemilikan institusional di dalam perusahaan dapat meningkatkan kinerja dan nilai perusahaan yakni diukur dengan nilai ROA dan Q.

(2.1) Hipotesis II :

Adanya pengaruh positif antara kepemilikan saham oleh manajemen perusahaan terhadap kinerja dan nilai perusahaan.

(2.2) Hasil Uji Regresi :

1. Nilai ROE pada signifikansi level 1 persen menunjukkan hubungan negatif signifikan antara kepemilikan saham oleh manajemen dengan kinerja perusahaan.

2. Adanya hubungan negatif (ROA) antara kepemilikan saham oleh manajemen dengan kinerja perusahaan.

3. Nilai $\mathrm{Q}$ menunjukkan hubungan negatif yang signifikan antara kepemilikan saham oleh manajemen dengan nilai perusahaan.

4. Nilai level 1 persen menunjukkan hubungan negatif yang signifikan antara kepemilikan saham oleh manajemen dengan harga saham.

Kesimpulan :

Tidak terbukti karena semakin besar kepemilikan manajerial di dalam perusahaan dapat memperburuk kinerja perusahaan apabila diukur dengan ROE dan harga saham.

\section{KESIMPULAN}

Tujuan penelitiaan ini adalah untuk mengetahui apakah kehadiran kepemilikan 
institusional dan kepemilikan manajerial memiliki pengaruh terhadap kinerja dan nilai perusahaan. Hasil dari penelitian ini: pertama, kehadiran kepemilikan saham institusional terbukti memiliki pengaruh positif yang signifikan terhadap kinerja perusahaan yang diukur dengan ROA serta memiliki hubungan positif terhadap nilai perusahaan yang diukur dengan nilai Q. Kedua, kehadiran kepemilikan saham manajerial terbukti memiliki pengaruh negatif terhadap kinerja perusahaan yang diukur menggunakan ROE, serta memiliki hubungan negatif terhadapa nilai perusahaan yang diukur dengan harga saham.

Implikasi penelitian ini: pertama, bagi perusahaan adalah bahan pertimbangan mengenai struktur kepemilikan institusional dan manajerial perusahaan serta pengaruhnya terhadap kinerja dan nilai perusahaan. Kedua, bagi akademisi adalah memberikan hasil empiris serta informasi mengenai dampak kehadiran pemegang saham institusional dan kepemilikan saham oleh manajemen terhadap kinerja dan nilai perusahaan. Ketiga, bagi investor adalah memberikan informasi dan bahan pertimbangan dalam berinvestasi di perusahaan mengenai pengaruh kepemilikan saham institusional serta kepemilikan manajerial terhadap kinerja dan nilai perusahaan. Keempat, bagi regulator adalah bahan pertimbangan dalam pembentukan dan pengesahan regulasi yang terkait dengan struktur kepemilikan.

Saran untuk memperbaiki penelitian ini: pertama, bagi peneliti menambah sumber lain, selain dari Capital IQ. Kedua, menambah indikator lain, selain Return on Assets, Return on Equity, Tobins 'Q, dan harga saham dalam mengukur kinerja dan nilai perusahaan. Ketiga, menambah variabel kontrol dan variabel independen kepemilikan saham lain, misalnya: perusahaan nonkeuangan, keluarga, pemerintah, dan individual. 


\section{Daftar Pustaka}

Adi, A. (2013). Pengaruh Return On Equity, Debt To Equity Ratio, Earning Per Share dan Book Value Per Share Terhadap Harga Saham (Studi pada Perusahaan Consumer Goods Industry yang Terdaftar di BEI Periode Tahun 2008-2011). Jurnal Administrasi Bisnis, 4(2).

Akhtar, S., Javed, B., Maryam, A., \& Sadia, H. (2012). Relationship between financial leverage and financial performance: Evidence from fuel \& energy sector of Pakistan. European Journal of Business and Management, 4(11),7-17.

Ardiyaningsih, A., \& Ardiyani, K. (2010). Analisis pengaruh struktur kepemilikan terhadap kinerja perusahaan. Pena Jurnal Ilmu Pengetahuan dan Teknologi, 19(2).

Ari Lina Wati, N. K., \& Ayu Darmayanti, N. P. (2013). Pengaruh Kepemilikan Manajerial dan Kinerja Keuangan Terhadap Kebijakan Dividen dan Nilai Perusahaan. E-Jurnal Manajemen Universitas Udayana, 2(12).

Arosa, B., Iturralde, T., \& Maseda, A. (2010). Ownership structure and firm performance in non-listed firms: Evidence from Spain. Journal of Family Business Strategy, 1(2), 8896.

Bae, K.-H., \& Jeong, S. W. (2007). The Value-relevance of Earnings and Book Value, Ownership Structure, and Business Group Affiliation: Evidence From Korean Business Groups. Journal of Business Finance \& Accounting, 34(5-6), 740-766.

Bapepam, T. S. P. E. (2002). Studi Penerapan ESOP Emiten atau Perusahaan Publik di 
Pasar Modal Indonesia. Bapepam.

Chaganti, R., \& Damanpour, F. (1991). Institutional ownership, capital structure, and firm performance. Strategic Management Journal, 12(7),479-491.

Cornett, M. M., Marcus, A. J., Saunders, A., \& Tehranian, H. (2007). The impact of institutional ownership on corporate operating performance. Journal of Banking \& Finance, 31(6),1771-1794.

Daraghma, Z. M., \& Alsinawi, A.-A. (2010). Board of directors, management ownership, and capital structure and its effect on performance: The case of palestine securities exchange. International Journal of Business and Management, 5(11),118.

Davies, J. R., Hillier, D., \& McColgan, P. (2005). Ownership structure, managerial behavior and corporate value. Journal of Corporate Finance, 11(4),645-660.

de la Cruz, A. M. P., Lizano, M. M., \& Madrid, E. M. (2014). Corporate Governance And Accuracy Level Of Financial Distress Prediction Models. The International Business \& Economics Research Journal (Online), 13(7),1619.

Demsetz, H., \& Villalonga, B. (2001). Ownership structure and corporate performance. Journal of Corporate Finance, 7(3),209-233.

Earle, J. S., Kucsera, C., \& Telegdy, Á. (2005). Ownership Concentration and Corporate Performance on the Budapest Stock Exchange: do too many cooks spoil the goulash? Corporate Governance: An International Review, 13(2),254-264.

Evaluation Measures: Evidence from the Tehran Stock Exchange. International Journal of Business and Commerce, 1(9),166-181.

Fazlzadeh, A., Hendi, A. T., \& Mahboubi, K. (2011). The examination of the effect of ownership structure on firm performance in listed firms of Tehran stock exchange based on the type of the industry. International Journal of Business and Management, 6(3),249.

Gujarati, D. N. (2003). Basic Econometrics. 4th. New York:McGraw-Hill.

Gürsoy, G., \& Aydoğan, K. (2002). Equity ownership structure, risk taking, and performance: an empirical investigation in Turkish listed companies. Emerging Markets Finance \& Trade,6-25.

Heflin, F., \& Shaw, K. W. (2000). Blockholder ownership and market liquidity. Journal of Financial and Quantitative Analysis, 35(4),621-633.

Hussain Tahir, S. (2015). Institutinoal Ownership and Corporate value: Evidence from Karachi Stock Exchange (KSE) 30-Index Pakistan. Praktični Menadžment, Stručni 
Časopis Za Teoriju I Praksu Menadžmenta, 6(1),41-49.

Islam, M. R., Khan, T. R., \& Adnan, T. T. C. A. M. (2014). How Earning Per Share (EPS) Affects on Share Price and Firm Value. European Journal of Business and Management, 6(17).

Jatmiko, D. P. (n.d.). The Influence of Agency Cost, Market Risk, and Investment Opportunities on Dividend Policy.2016.

Joh, S. W. (2003). Corporate governance and firm profitability: evidence from Korea before the economic crisis. Journal of Financial Economics, 68(2),287-322.

Jusoh, M. A., Katmun, N., Katmon, N. H. A. R., \& Ismail, K. (2014). Managerial Ownership and Market-based Performance Indicators: Extended Agency Theory.

Kaserer, C., \& Moldenhauer, B. (2008). Insider ownership and corporate performance: evidence from Germany. Review of Managerial Science, 2(1), 1- 35.

Kibet, T. W., \& Jagongo, A. O. (n.d.). Effects of Dividend Policy on Share Price of Firms Listed at the Nairobi Securities Exchange,Kenya.

Lee, S. (2008). Ownership structure and financial performance: Evidence from panel data of South Korea. Corporate Ownership and Control,6(2).

Liang, C.-J., Lin, Y.-L., \& Huang, T.-T. (2011). Does multi-dimensional ownership structure matter in firm performance? A dynamic firm's life cycle perspective. The International Journal of Business and Finance Research, 5(2),1-19.

McConnell, J. J., \& Servaes, H. (1990). Additional evidence on equity ownership and corporate value. Journal of Financial Economics, 27(2),595-612.

Musyoki, D. (2012). Changes in share prices as a predictor of accounting earnings for financial firms listed in Nairobi Securities Exchange. International Journal of Business and Public Management, 2(2),1-11.

Na, S.-K. (2002). Ownership structure and firm performance in Korea.

Nuraina, E. (2012). Pengaruh Kepemilikan Institusional dan Ukuran Perusahaan terhadap Kebijakan Hutang dan Nilai Perusahaan (Studi Pada Perusahaan Manufaktur yang Terdaftar di BEI). Jurnal AKRUAL, 4(1).

Onaolapo, A. A., \& Kajola, S. O. (2010). Capital structure and firm performance: evidence from Nigeria. European Journal of Economics, Finance and Administrative Sciences, $25,70-82$.

Osunsan, O. K., Nowak, J., Mabonga, E., Pule, S., Kibirige, A. R., \& Baliruno, J. B. (2015). Firm Age and Performance in Kampala, Uganda: A Selection of Small Business 
Enterprises. International Journal of Academic Research in Business and Social Sciences, 5(4),364-374.

Ozgulbas, N., Koyuncugil, A. S., \& Yilmaz, F. (2006). Identifying the effect of firm size on financial performance of SMEs. The Business Review, Cambridge, 6(1), 162-167.

Park, H. M. (2005). Linear regression models for panel data using SAS, Stata, LIMDEP, and SPSS. Indiana University.

Park, H. M. (2011). Practical guides to panel data modeling: a step-by-step analysis using stata. Public Management \& Policy Analysis Program, International University of Japan.

Rose, C. (2005). Managerial Ownership and Firm Performance in ListedDanish Firms:: In Search of the Missing Link. European Management Journal,23(5),542-553.

Simoneti, M., \& Gregoric, A. (2004). Managerial ownership and corporate performance in Slovenian post-privatisation period. The European Journal of Comparative Economics, 1(2),217.

Thanatawee, Y. (2014). Institutional Ownership and Firm Value in Thailand. Asian Journal of Business and Accounting,7(2).

Tobin, J., \& Brainard, W. C. (1977). Asset markets and the cost of capital. Economic Progress, Private Values, and Public Policy. North Holland, Amsterdam, 235-62.

Uno, J., \& Kamiyama, N. (2010). Ownership structure, liquidity, and firm value. Unpublished Manuscript, Waseda University.

Vo, D. H., \& Nguyen, V. T.-Y. (2014). Managerial Ownership, Leverage and Dividend Policies: Empirical Evidence from Vietnam's Listed Firms. International Journal of Economics and Finance, 6(5),274. 